\title{
Author Correction: Cryptic inoviruses revealed as pervasive in bacteria and archaea across Earth's biomes
}

Simon Roux D, Mart Krupovic D, Rebecca A. Daly, Adair L. Borges, Stephen Nayfach, Frederik Schulz (D), Allison Sharrar, Paula B. Matheus Carnevali D, Jan-Fang Cheng, Natalia N. Ivanova D, Joseph Bondy-Denomy, Kelly C. Wrighton, Tanja Woyke (D), Axel Visel (D), Nikos C. Kyrpides and Emiley A. Eloe-Fadrosh (D)

Correction to: Nature Microbiology https://doi.org/10.1038/s41564-019-0510-x, published online 22 July 2019.

In the version of this Article originally published, in the Data availability section, the link 'https://genome.jgi.doe.gov/portal/PhyloTag/ PhyloTag.home.html' was incorrect; it should have been 'https://genome.jgi.doe.gov/portal/Inovirus/Inovirus.home.html'. This has now been corrected.

Open Access This article is licensed under a Creative Commons Attribution 4.0 International License, which permits use, sharing, adaptation, distribution and
reproduction in any medium or format, as long as you give appropriate credit to the original author(s) and the source, provide a link to the Creative Commons
license, and indicate if changes were made. The images or other third party material in this article are included in the article's Creative Commons license, unless
indicated otherwise in a credit line to the material. If material is not included in the article's Creative Commons license and your intended use is not permitted by statutory regula-
tion or exceeds the permitted use, you will need to obtain permission directly from the copyright holder. To view a copy of this license, visit http://creativecommons.org/licenses/
by/4.0\%.

by/4.0/.

Published online: 11 February 2020

https://doi.org/10.1038/s41564-020-0681-5

(c) This is a U.S. government work and not under copyright protection in the U.S.; foreign copyright may apply 2020 